\title{
The Diagnosis of Urinary Tract Infection
}

\author{
A Systematic Review
}

Guido Schmiemann, Eberhardt Kniehl, Klaus Gebhardt, Martha M. Matejczyk, Eva Hummers-Pradier

\section{SUMMARY}

Background: Urinary tract infections (UTI) are among the leading reasons for treatment in adult primary care medicine, accounting for a considerable percentage of antibiotic prescriptions. Because this problem is so common and so significant in routine clinical practice, a high level of diagnostic accuracy is essential. Antibiotics should not be prescribed excessively, particularly in view of the increasing prevalence of antibiotic resistance.

Method: Systematic review of relevant articles that were retrieved by a search of the Medline, Embase, and Cochrane Library databases. The recommendations of selected international guidelines were also taken into account, as were the German national quality standards for microbiological diagnosis.

Results: The diagnosis of UTI by clinical criteria alone has an error rate of approximately $33 \%$. The use of refined diagnostic algorithms does not completely eliminate uncertainty.

Conclusion: With the aid of a small number of additional diagnostic criteria, antibiotic treatment for UTI can be provided more specifically and thus more effectively. Differentiating UTI from asymptomatic bacteriuria, which usually requires no treatment, can lower the frequency of unnecessary antibiotic prescriptions.
Gite this as: Dtsch Arztebl Int 2010; 107(21): 361-7 DOl: 10.3238/arztebl.2010.0361

Institut für Allgemeinmedizin, Medizinische Hochschule Hannover: Dr. med. Schmiemann, Prof. Dr. med. Hummers-Pradier

Zentrum für Labormedizin, Städtisches Klinikum Karlsruhe: Dr. med. Kniehl Kreiskrankenhaus Eschwege/Zentrum Innere Medizin: Dr. med. Matejczyk Hausärztliche Gemeinschaftspraxis, Bremen: Gebhardt nfections of the lower urinary tract (acute cystitis) are one of the most frequent diseases in primary medical care which are treated with antibiotics. Urinary tract infections (UTI) are responsible for $1 \%$ to $3 \%$ of all consultations in Great Britain (1). The prevalence is highly dependent on age and gender (Figure). If a female patient presents to a primary care practice with the typical symptoms, the probability is $50 \%$ to $80 \%$ that she has an infection of the urinary tract (Table 1).

The guideline recommendations for the antibiotic treatment of infections of the urinary tract are often not implemented in practice. National and international recommendations warn against the broad and uncritical use of fluoroquinolones for uncomplicated infections $(2,3)$. The numbers of prescriptions show how widely these recommendations are ignored in practice (4). These prescription practices have led to increasing resistance and endanger the use of fluoroquinolones in severe infections (5). Nitrofurantoin is a possible alternative, but is hardly prescribed, as the German recommendation for its use is very restricted in comparison to other countries: "Nitrofurantoin may only be administered when more effective and safer antibiotics or chemotherapy agents cannot be used" [translated from the German Summary of Product Characteristics for Nitrofurantoin, www.fachinfo.de]. The use of amoxicillin and (to some extent) of trimethoprim is restricted by the marked increase in the number of resistant pathogens. In this context, it has become ever more important that antibiotics should be used rationally and specifically in the treatment of UTI.

The vast majority of cases of urinary tract infection in outpatients are uncomplicated. It is assumed that UTI is complicated when there are risk factors for a severe clinical course or for secondary harms (Box).

However, some of the factors which have been described as leading to complicated disease are of doubtful significance. There are special recommendations for complicated UTI, as greater diagnostic accuracy and different therapeutic strategies are necessary.

The present article presents the most important diagnostic procedures, together with their role in establishing the diagnosis. This should increase diagnostic accuracy and allow specific use of antibiotic therapy.

\section{Definition}

The gold standard for the diagnosis of a urinary tract infection is the detection of the pathogen in the 


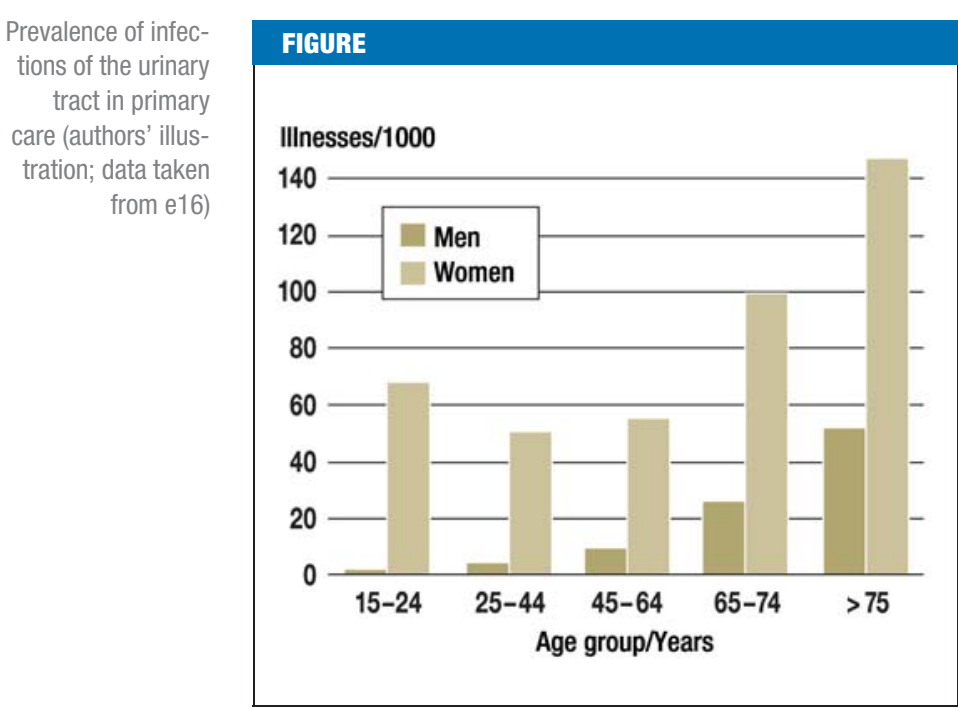

presence of clinical symptoms. The pathogen is detected and identified by urine culture (using midstream urine). This also allows an estimate of the level of the bacteriuria. However, the minimum level of bacteriuria demonstrating an infection of the urinary tract has not been defined in scientific literature or standardized by microbiological laboratories. Many laboratories define $10^{5}$ colony forming units $(\mathrm{cfu}) / \mathrm{mL}$ urine as the threshold. However, this threshold misses many relevant infections. There are therefore other recommendations (2, 5) that recommend the diagnosis of UTI from a count of $10^{3} \mathrm{cfu} / \mathrm{mL}$, depending on the types of bacteria detected.

\section{Definition of asymptomatic bacteriuria}

Asymptomatic bacteriuria ( $\mathrm{ABU}$ ) is present if a patient does not exhibit the clinical signs of UTI and the upper limit of $\geq 10^{5} \mathrm{cfu} / \mathrm{mL}$ is exceeded in two consecutive properly collected samples of midstream urine (from women). A single detection is adequate for men. Screening and treatment of asymptomatic bacteriuria is only necessary in exceptional cases (22), for example, in pregnant women or before a urological operation.

\section{Methods}

All relevant articles in German and English published after the DEGAM (Deutsche Gesellschaft für Allgemeinmedizin und Familienmedizin, German College of General Practitioners and Family Physicians) guideline on "Dysuria" (including a systematic review) in January 1999 were retrieved from the databases of Medline, Embase, CCMed and the Cochrane Database of Systematic Reviews (January 1999 to July 2007). The following keywords were used (each with the AND connection):

- urinary tract infections general practice

- urinary tract infections primary care

- diagnosis urinary tract infections general practice
- diagnosis urinary tract infections primary care

- urinalysis nitrites leukocytes esterases

- cystitis general practice

- cystitis primary medical care

- urine primary care

- antibiotic resistance urinary tract infections

- epidemiology urinary tract infections

- guidelines general practice urinary

- guidelines primary care urinary

- urine general practice

- urinary tract infections pregnancy.

For the present article, the search was updated to July 2009 in Medline, CCMed and the Cochrane database. Within this period, the authors only specifically searched for studies on diagnostic testing. The algorithm was: (urin* tract infection or cystitis) AND (sensitiv*[Title/Abstract] OR sensitivity and specificity[MeSH terms] OR diagnos*[Title/Abstract] OR diagnosis[MeSH:noexp] OR diagnostic*[MeSH:noexp] OR diagnosis, differential[MeSH:noexp] OR diagnosis [subheading:noexp]). In the Cochrane database, the search term MeSH descriptor Urinary Tract Infections was used. The search included clinical studies, guidelines, and review articles or meta-analyses, containing information about symptom evaluation, urine collection or diagnostic precision.

The reference lists of the articles found were examined for additional relevant studies. Individual authors were contacted for missing data. The guidelines of the relevant medical societies and the "Microbiological Quality Standards for Infectious Diseases (MIQ)" (6) and the results of expert discussions within the S3 guideline group on "Infections of the Urinary Tract" were also considered.

\section{Results}

The literature search for the guideline found 3993 articles in Medline and 483 articles in the Cochrane database. These were not differentiated by category. We included a total of 89 articles on diagnostic testing. The update found 263 articles in Pubmed and 16 of these were included. The remaining articles were excluded, either because the theme was not appropriate $(n=238)$, or because of a different setting or patient group $(n=9)$. No current articles on diagnostic testing were found in the Cochrane database.

\section{Medical history}

The clinical diagnosis of an infection of the urinary tract is essentially based on the medical history. Specific data may either increase the probability of an infection of the urinary tract $(\uparrow)$ or decrease it $(\downarrow)$. The following factors have been established from clinical studies $(7,8)$ :

- Dysuria, pollakisuria, nycturia $(\uparrow)$

- Present or increased incontinence $(\uparrow)$

- Macrohematuria $(\uparrow)$

- Suprapubic pain $(\uparrow)$

- "Offensive" smell, turbid urine $(\uparrow)$

- Prior infections of the urinary tract $(\uparrow)$ 


\section{Diagnostic testing with dip sticks}

\begin{tabular}{|c|c|c|c|c|c|c|c|c|c|c|c|}
\hline Source & $\begin{array}{l}\text { Bacterial } \\
\text { count } \\
\text { cfu/mL }\end{array}$ & $\begin{array}{l}\text { Preva- } \\
\text { lence }\end{array}$ & $\mathrm{n}$ & Test & Sens $\%$ & Spec \% & PPV \% & NPV \% & $\mathrm{LR}+$ & LR - & Comments \\
\hline \multirow[t]{2}{*}{ Mclsaac (15) } & $>10^{2}$ & $63 \%$ & 331 & $\mathrm{Ni}$ & 36 & 89 & 85 & 45 & 3.4 & 0.7 & \multirow[t]{2}{*}{$10 \%$ with discharge } \\
\hline & & & & Le & 84 & 45 & 72 & 63 & 1.5 & 0.35 & \\
\hline \multirow[t]{2}{*}{ Grude 2005 (e11) } & $>10^{4}$ & $76 \%$ & 184 & Le & 94 & 9 & 86 & 20 & 1.0 & 0.6 & \\
\hline & & & & $\mathrm{Ni}$ & 57 & 78 & 94 & 23 & 2.6 & 0.5 & \\
\hline Winkens (24) & $>10^{5}$ & $62 \%$ & 268 & $\mathrm{Ni}$ & 42 & 95 & 93 & 50 & 8.4 & 0.6 & $17 \%$ men \\
\hline \multirow[t]{3}{*}{ Verest 2000 (e12) } & $>10^{5}$ & $58 \%$ & 292 & Le & 88 & 37 & 63 & 71 & 1.4 & 0.3 & \\
\hline & & & & $\mathrm{Ni}$ & 53 & 95 & 93 & 59 & 10.6 & 0.5 & \\
\hline & & & & $\begin{array}{l}\mathrm{Ni}+ \\
\text { Le neg }\end{array}$ & & & & 81 & & & \\
\hline \multirow[t]{3}{*}{ Deville (e13) } & k.A & & k.A & $\mathrm{Ni}$ & 53 & 88 & & & 4.4 & & \multirow{3}{*}{$\begin{array}{l}\text { - Metaanalysis of sub- } \\
\text { group "General Prac- } \\
\text { tice", no differenti- } \\
\text { ation by sex }\end{array}$} \\
\hline & & & & Le & 87 & 36 & & & 1.3 & & \\
\hline & & & & $\begin{array}{l}\mathrm{Ni}+ \\
\text { Le pos }\end{array}$ & 90 & 65 & & & 2.5 & & \\
\hline \multirow[t]{2}{*}{ Heckerling 2007 (e9) } & $>10^{5}$ & $26 \%$ & 212 & $\mathrm{Ni}$ & & & & & 1.5 & & \multirow{2}{*}{$\begin{array}{l}\text { - With diagnostic defi- } \\
\text { nition of }>10^{2} \text { bacte- } \\
\text { ria, prevalence rises } \\
\text { to } 55 \%\end{array}$} \\
\hline & & & & Le & & & & & 1.5 & & \\
\hline \multirow[t]{3}{*}{ Semeniuk 1999 (e14) } & $>10^{4}$ & $19 \%$ & 479 & $\mathrm{Ni}$ & 43 & 97 & 75 & 88 & 14 & & \multirow[t]{3}{*}{$\begin{array}{l}\text { Inclusion criteria } \\
\text { unclear }\end{array}$} \\
\hline & & & & Le & 84 & 59 & 19 & 97 & 2 & & \\
\hline & & & & $\begin{array}{l}\mathrm{Ni}+ \\
\text { Le pos }\end{array}$ & 84 & 98 & 84 & 98 & 42 & & \\
\hline \multirow[t]{3}{*}{ Little (8) } & $>10^{3}$ & $62.5 \%$ & 427 & Blut & 93 & 34 & 70 & 73 & 1.4 & 0.22 & \multirow{3}{*}{$\begin{array}{l}\text { Presence of vaginal } \\
\text { discharge led to exclu- } \\
\text { sion }\end{array}$} \\
\hline & & & & Le & 89 & 52 & 75 & 72 & 2.58 & 0.33 & \\
\hline & & & & $\begin{array}{l}\mathrm{Ni}+ \\
\text { Le pos }\end{array}$ & 26 & 97 & 93 & 44 & 8.0 & 0.77 & \\
\hline \multirow[t]{3}{*}{ Hummers-Pradier (20) } & $>10^{2}$ & $77 \%$ & 445 & $\mathrm{Ni}$ & 39 & 88 & 92 & 29 & 3.3 & 0.7 & \multirow[t]{3}{*}{$\begin{array}{l}\text { Complicated UTI } \\
\text { excluded }\end{array}$} \\
\hline & & & & Le & 72 & 46 & 83 & 31 & 1.3 & 0.6 & \\
\hline & & & & $\begin{array}{l}\mathrm{Ni}+ \\
\text { Le pos }\end{array}$ & 35 & 88 & 91 & 27 & 2.9 & 0.7 & \\
\hline
\end{tabular}

Overview of studies for the diagnosis of a urinary tract infection; inclusion criteria: primary care setting; reason for consultation: women with symptoms when passing water; comparison with urine culture as gold standard; sens, sensitivity; spec, specificity; PPV, positive predictive value; NPV, negative predictive value; LR, likelihood ratio; Le, leukocyte esterase; Ni, nitrite. Missing values are either not given in the sources or cannot be calculated from the available data.

- Changed or new discharge, vaginal irritation $(\downarrow)$. In addition, risk factors are known which increase the probability of UTI. These include:

- Sexual intercourse within the preceding two weeks (9)

- Contraception with a vaginal diaphragm or spermicide (10)

- Contraception with DMPA (depot medroxyprogesterone acetate) (11)

- Antibiotic administration within the preceding two to four weeks (12)

- Special anatomical features or restrictions (for example, from vesicoureteral reflux, neuropathic bladder, mechanical or functional obstruction)

(13)

- Diabetes mellitus (14).

\section{Urine testing}

Urine testing is the second important element in diagnostic testing.

\section{Urine collection}

Several studies have dealt with the necessity of collecting midstream urine and of cleaning the perineum and vulva or glans penis (3, e5, e6). However, these were mostly with fairly young and otherwise healthy 
BOX

\section{Complicated infections of the urinary tract (3)}

- All infections of the urinary tract in children, men and pregnant women

- Special functional or anatomical features

- Immune suppressed patients

- Urological or renal disease, kidney stones

- Status after laying a urine catheter, discharge from an inpatient facility within the previous two weeks women, so it is not clear whether they can be transferred to normal clinical practice. A pragmatic solution would be to make the method of urine collection dependent on the clinical problem. For an initial urine investigation with a dip stick, fresh spontaneous urine can be taken rather than midstream urine and it is unnecessary to clean the genitals. On the other hand, additional studies and urine culture require that the urine sample should be collected and processed with as little contamination as possible.

\section{Practical test methods}

The gold standard for a urine test is to perform a bacteriological urine culture, with identification of the pathogen, with quantification and sensitivity testing. To test whether the patient has a UTI at all, orientating indirect methods are often used in practice to detect the bacteria or inflammation (dip sticks). The bacterial count may be assessed by urine microscopy and immersion culture media.

\section{Dip sticks}

Urine dip sticks are one of the most frequently used instruments for diagnostic testing if there is clinical evidence that a patient is suffering from UTI. Multistix are most often used, which may be able to detect nitrite (a metabolic product of typical pathogens of the urinary tract), leukocyte esterase, protein and blood (as a marker of inflammation).

If nitrite is detected, this increases the probability of a urinary tract infection, with a likelihood ratio [LR] of 2.6 to 10.6 . However, the sensitivity is relatively low. In contrast, the detection of leukocyte esterase increases the probability to a lesser degree (LR 1.0 to 2.6). The detection of blood is admittedly highly sensitive, but the specificity is low. Study data are inconsistent about the value of protein detection in confirming UTI. Table 1 summarizes the sensitivity and specificity of dip sticks.

\section{Urine microscopy}

Due to methodological limitations the sensitivity in detecting UTI with $<10^{5} \mathrm{cfu} / \mathrm{mL}$ by gram stained microscopy is low. Some studies have found that experienced workers can achieve better diagnostic precision than with urine culture. However, the available studies on microscopy are heterogenous and all review articles conclude that it is difficult to make general statements (23).

\section{Immersion culture media}

These immersion tests use a plastic rod coated with culture medium - mostly a combination of CLED agar and MacConkey agar. They require $24 \mathrm{~h}$ culture. The values for sensitivity and specificity obtained in the laboratory cannot be reproduced under the conditions of primary care (24). In the primary care setting, the sensitivity was found to be $73 \%$ (95\% confidence interval [CI] 66-80) and the specificity 94\% (CI 88-98). If a female patient has previously had a negative nitrite test, the sensitivity is reduced to $65 \%$ (CI 55-74), with virtually the same specificity (CI 90-99). This procedure does not permit the reliable detection of $<10^{4} \mathrm{cfu} / \mathrm{mL}$ (6).

\section{Use of diagnostic algorithms}

Clinical algorithms have been developed and tested, in an attempt to increase diagnostic precision, and thus to allow more specific use of calculated antibiotic treatment. However, it has not yet been possible to compare these algorithms directly, as they employ different reference methods (threshold bacterial counts) (Table 2). A UTI with a low bacterial count is most reliably detected with the algorithm used by McIsaac (15):

- Burning sensation or discomfort when passing urine

- Detection of leukocytes

- Any detection of nitrite.

The diagnostic criterion is then the presence of at least two test criteria (sensitivity $80 \%$, specificity $54 \%$ ). Additional urine microscopy only slightly improves the probability of detection.

However, the specificity of this algorithm is low, so that it gives a high rate of false positives. This means that it fails to give a reduction in the number of unnecessary prescriptions of antibiotics. As an alternative, the following point system may be used:

- Nitrite positive $=2$

- Leukocytes positive $=1.5$

- Hematuria $=1$

- Moderately severe dysuria $=1$

- Moderately severe nocturia $=0.5$

This gives sensitivity of $76 \%$ and specificity of $74 \%$ (16).

\section{Diagnostic testing in special patient groups}

For the (relatively frequent) case of uncomplicated UTI, it is usually sufficient to diagnose UTI solely on the basis of these indirect test methods. For all therapy-resistant and complicated infections of the 


\section{TABLE 2}

Various algorithms to improve diagnostic testing for uncomplicated cystitis

\begin{tabular}{|c|c|c|c|c|c|}
\hline Source & $\begin{array}{l}\text { Bacterial } \\
\text { count } \\
\text { cfu/mL }\end{array}$ & Prevalence & Algorithm & $\begin{array}{l}\text { Sensitivity } \\
\text { Specificity ( } 95 \% \\
\text { confidence interval) }\end{array}$ & Comment \\
\hline $\begin{array}{l}\text { Heckerling } 2007 \\
\text { (e9) }\end{array}$ & $\geq 10^{5}$ & $26 \%$ & $\begin{array}{l}\text { - Frequent urinary urgency } \\
\text { - Foul smell to urine } \\
\text { - Positive dip stick for leukocyte } \\
\text { esterase } \\
\text { - Microscopic detection of bacte- } \\
\text { ria and epithelia }\end{array}$ & $\begin{array}{l}\text { Sens: } 0.82(0.69-0.91) \\
\text { Spec: } 0.74(0.67-0.81)\end{array}$ & \\
\hline $\begin{array}{l}\text { Heckerling } 2007 \\
\text { (e9) }\end{array}$ & $\geq 10^{2}$ & $55 \%$ & $\begin{array}{l}\text { - Dysuria } \\
\text { - Symptoms for less than } 3 \text { days } \\
\text { - No diabetes } \\
\text { - Microscopic detection of ery- } \\
\text { throcytes and bacteria }\end{array}$ & $\begin{array}{l}\text { No information on sensitiv- } \\
\text { ity or specificity } \\
\text { ROC=0.792 } \\
(95 \% \mathrm{Cl}: 0.726-0.858)\end{array}$ & \\
\hline Mclsaac (15) & $\geq 10^{2}$ & $63 \%$ & $\begin{array}{l}\text { - Discomfort or burning sen- } \\
\text { sation when passing water } \\
\text { - Detection of leukocytes (more } \\
\text { than a trace) } \\
\text { - Any detection of nitrite } \\
\text { - Positive when two or more } \\
\text { criteria fulfilled }\end{array}$ & $\begin{array}{l}\text { Sens: } 80.3 \%(74.2-85.5) \\
\text { Spec: } 53.7 \%(44.4-62.7)\end{array}$ & \\
\hline Winkens (24) & $\geq 10^{5}$ & $62 \%$ & $\begin{array}{l}\text { Use of immersion culture after } \\
\text { prior negative nitrite test } \\
\text { Read after } 24 \mathrm{~h}\end{array}$ & $\begin{array}{l}\text { Sens: } 64.9 \% \text { (ND) } \\
\text { Spec: } 94.8 \% \text { (ND) }\end{array}$ & \\
\hline Little (8) & $\geq 10^{3}$ & $62.5 \%$ & $\begin{array}{l}\text { - Dysuria } \\
\text { - Nycturia } \\
\text { - "Offensive" smell } \\
\text { - Turbid urine } \\
\text { - Nitrite positive } \\
\text { - Blood and leukocytes positive } \\
\text { - Positive when two or more } \\
\text { criteria fulfilled }\end{array}$ & $\begin{array}{l}\text { Sens: } 65 \%(58.7-70.5) \\
\text { Spec: } 69 \%(61.5-76.1)\end{array}$ & \\
\hline Little (8) & $\geq 10^{3}$ & $62.5 \%$ & $\begin{array}{l}\text { Detection of nitrite or blood and } \\
\text { leukocytes with dip sticks }\end{array}$ & $\begin{array}{l}\text { Sens: } 77 \%(72.0-82.4) \\
\text { Spec: } 70 \%(62.9-77.3)\end{array}$ & $\begin{array}{l}75 \% \text { of patients } \\
\text { were correctly } \\
\text { classified with } \\
\text { this rule }\end{array}$ \\
\hline Mclsaac 2002 (e10) & $\geq 10^{4}$ & $53 \%$ & $\begin{array}{l}\text { - Symptoms for a day } \\
\text { - Dysuria } \\
\text { - Detection of leukocytes or nitrite }\end{array}$ & $\begin{array}{l}\text { Sens: } 81.3 \% \text { (ND) } \\
\text { Spec: } 64.5 \% \text { (ND) }\end{array}$ & \\
\hline
\end{tabular}

ROC, receiver operating characteristics, ND = no data; sens, sensitivity; spec, specificity

urinary tract (Box), an attempt should generally be made to perform a urine culture to detect the causative organisms and their antimicrobial susceptibility $(2,5)$.

\section{Pregnant women}

Treatment of asymptomatic bacteriuria (ABU) in pregnant women decreases the occurrence of pyelonephritis (number needed to treat $[\mathrm{NNT}]=7)(25)$ and possibly also damage to the child (e7, e8). However, the dip stick used in current antenatal care testing is rather insensitive. If immersion culture media were generally used, this would give a detection rate for asymptomatic bacteriuria comparable to that with urine culture (e15). There are however no unambiguous published data about the best time to perform such a urine test $(17,18)$.

\section{Female geriatric patients}

The prevalence of asymptomatic bacteriuria markedly increases in this group. Thus, the prevalence in residents of homes for the elderly is $25 \%$ to $50 \%$, even rising to $100 \%$ in catheterized patients. In the latter group, neither dip sticks nor urine culture is useful in confirming the clinical diagnosis of UTI. Only a negative urine culture can exclude an infection. An American consensus conference (19) has drafted special diagnostic criteria for this group, which have led to a reduction in antibiotic prescriptions in nursing homes.

\section{Female patients with diabetes mellitus}

Female patients with medically treated diabetes frequently exhibit a urinary tract infection or $\mathrm{ABU}$. The 
spectrum of bacteria and resistance rates are not distinct in this group $(14, \mathrm{e} 1)$. It is therefore reasonable to question the current practice of assigning this group to the complicated urinary tract infections.

\section{Men}

Urinary tract infections in men are still regarded as complicated urinary tract infections. As testing with dip sticks is imprecise in this group, it is recommended that urine culture should be performed to confirm the diagnosis. Unfortunately, hardly any therapeutic or diagnostic studies have been performed for men (e2).

\section{Discussion}

Sensitivity based on a typical history is between $50 \%$ and $80 \%(7,20)$. Immediate therapy, without additional diagnostic testing, is thus an enticing option and is quite conventional in many countries.

This approach implies maximal sensitivity-all cases of UTI are treated, but many false positives are accepted. Bearing in mind the increasing development of resistance, it must be called into question.

Absolute diagnostic reliability and maximally specific therapy would only be achieved if the gold standard-urine culture-was generally used. This approach would require considerable additional effort, but would be capable of greatly reducing the rate of antibiotic prescriptions. On the other hand, this would delay specific antibiotic therapy. One current demand is for empirical therapy, together with preparation of a urine culture at the same time. This is an additional possibility, at least in some situations - such as in nursing homes (21). A current study is to evaluate the factors influencing the different diagnostic steps and this may lead to improvements in the current algorithms (e3).

If a decision is to be made between these two strategies, it would have to be based on a variety of different factors, only some of which are measurable with specified criteria. Subjective ascription of importance and personal feelings are just as important:

- Morbidity and mortality: How severe is the disease from the points of view of the physician and patient? If antibiotics are not used for treating uncomplicated UTI, the course of the disease will not be more severe. Although pyelonephritis is often dreaded, its incidence is not significantly greater if the treatment is only with placebo. However, antibiotic treatment can significantly reduce the duration of the symptoms, by as long as two days (e4). On the other hand, asymptomatic bacteriuria need only be treated in exceptional cases.

- The wishes of the patient: The wishes of the patient and the physician are often different. The physician must establish what the patient wants and must consider this when deciding on the therapy.

- Infrastructure: Potentially more precise tests (such as microscopy) are not available in most primary care practices. It is also essential that the physician has the appropriate experience.

Because of the increased development of resistance, new strategies are needed for the treatment of infections of the urinary tract. Diagnostic algorithms can help to make the use of antibiotics more specific.

\section{Conflict of interest statement \\ The authors declare that no conflict of interest exists according to the guidelines of the International Committee of Medical Journal Editors.}

Manuscript received on 6 April 2009, revised version accepted on 26 August 2009

Translated from the original German by Rodney A. Yeates, M.A., Ph.D.

\section{REFERENCES}

1. MeReC Bulletin Volume 17, Number 3; www.npc.co.uk/ MeReC_Bulletins/MeReC_Bulletin_Vol17_No3_Intro.htm

2. Schmiemann G, Gebhardt K, Matejczyk M, Hummers-Pradier E: DEGAM-Leitlinie Nr. 1: Brennen beim Wasserlassen - Update 2009. Omikron publishing: Düsseldorf 2009.

3. Samenvattingskaart NHG-Standaard: URINEWEGINFECTIES NHGSTANDAARD. http://nhg.artsennet.nl/upload/104/standaarden/ M05/start.html

4. GEK-Arzneimittel-Report 2009. http://www.gek.de/x-medien/da teien/magazine/GEK-Arzneimittel-Report-2009.pdf

5. EAU (European Association of Urology). Guidelines on Urological Infections. European Association of Urology, 2009. http://www.uro web.org/nc/professional-resources/guidelines/online/

6. Gatermann S, Fünfstück R, Handrick W, et al.: Harnwegsinfektion Mikrobiologisch-infektologische Qualitätsstandards. In: Mauch M, Podbielski A, Hermann M (eds.): München, Jena: Urban \& Fischer 2005; 8-21.

7. Bent S, Saint S: The optimal use of diagnostic testing in women with acute uncomplicated cystitis. Am J Med 2002; 113 (Suppl 1A): 20-8.

8. Little P, Turner S, Rumsby K, et al.: Developing clinical rules to predict urinary tract infection in primary care settings: sensitivity and specificity of near patient tests (dipsticks) and clinical scores. Br J Gen Pract 2006; 56: 606-12.

9. Foxman B, Geiger AM, Palin K, Gillespie B, Koopman JS: First-time urinary tract infection and sexual behavior. Epidemiology 1995; 6: 162-8.

10. Fihn SD, Boyko EJ, Normand EH, et al.: Association between use of spermicide-coated condoms and Escherichia coli urinary tract infection in young women. Am J Epidemiol 1996; 144: 512-20.

11. Ziaei S, Ninavaei M, Faghihzadeh S: Urinary tract infection in the users of depot-medroxyprogesterone acetate. Acta Obstet Gynecol Scand 2004; 83: 909-11.

12. Smith HS, Hughes JP, Hooton TM, et al.: Antecedent antimicrobial use increases the risk of uncomplicated cystitis in young women. Clin Infect Dis 1997; 25: 63-8.

\section{KEY MESSAGES}

- Infections of the urinary tract are one of the most frequent reasons for treatment in primary medical care.

- Diagnosis solely based on clinical symptoms is often wrong.

- Asymptomatic bacteriuria only requires treatment in exceptional cases.

- Diagnostic precision can be increased by using dip sticks and clinical algorithms. 
13. Agarwal S: Vesicoureteral reflux and urinary tract infections. Curr Opin Urol 2000; 10: 587-92.

14. Boyko EJ, Fihn SD, Scholes D, Abraham L, Monsey B: Risk of urinary tract infection and asymptomatic bacteriuria among diabetic and nondiabetic postmenopausal women. Am J Epidemiol 2005; 161: 557-64.

15. Mclsaac WJ, Moineddin R, Ross S: Validation of a decision aid to assist physicians in reducing unnecessary antibiotic drug use for acute cystitis. Arch Intern Med 2007; 167: 2201-6.

16. Little P, Turner S, Rumsby K, et al.: Dipsticks and diagnostic algorithms in urinary tract infection: development and validation, randomized trial, economic analysis, observational cohort and qualitative study. Health Technol Assess 2009; 13: ii-iv, ix-xi, 1-73.

17. McNair RD, MacDonald SR, Dooley SL, Peterson LR: Evaluation of the centrifuged and Gram-stained smear, urinalysis, and reagent strip testing to detect asymptomatic bacteriuria in obstetric patients. Am J Obstet Gynecol 2000; 182: 1076-9.

18. Mclsaac W, Carroll JC, Biringer A, et al.: Screening for asymptomatic bacteriuria in pregnancy. J Obstet Gynaecol Can 2005; 27 : 20-4.

19. Loeb M, Bentley DW, Bradley S, et al.: Development of minimum criteria for the initiation of antibiotics in infect. Control Hosp Epidemiol 2001; 22: 120-4.

20. Hummers-Pradier E, Koch M, Ohse AM, Heizmann WR, Kochen MM: Antibiotic resistance of urinary pathogens in female general practice patients. Scand J Infect Dis 2005; 37: 256-61.
21. Sundqvist M, Kahlmeter G: "Pre-emptive culturing" will improve the chance of "getting it right" when empirical therapy of urinary tract infections fails. J Antimicrob Chemother 2009; 64: 227-8.

22. Lin K, Fajardo K: Screening for asymptomatic bacteriuria in adults: evidence for the U.S. preventive services task force reaffirmation recommendation statement. Ann Intern Med 2008; 149: 20-4.

23. Whiting P, Westwood M, Bojke L, et al.: Clinical effectiveness and cost-effectiveness of tests for the diagnosis and investigation of urinary tract infection in children: a systematic review and economic model. Health Technol Assess 2006; 10: iii-iv, xi-xiii, 1-154.

24. Winkens R, Nelissen-Arets $H$, Stobberingh E: Validity of the urine dipslide under daily practice conditions. Fam Pract 2003; 20: 410-2.

25. Smaill F: Antibiotics for asymptomatic bacteriuria in pregnancy. The Cochrane Database of Systematic Reviews 2007, Issue 2. Art. No.:CD000490. DOI: 10.1002/14651858.CD000490.

\section{Corresponding author}

Dr. med. Guido Schmiemann, MPH

Institut für Allgemeinmedizin

Medizinische Hochschule Hannover

30625 Hannover, Germany

schmiemann.guido@mh-hannover.de

(D) For e-references please refer to: www.aerzteblatt-international.de/ref2110 
ORIGINAL ARTICLE

\title{
The Diagnosis of Urinary Tract Infection
}

\author{
A Systematic Review
}

Guido Schmiemann, Eberhardt Kniehl, Klaus Gebhardt, Martha M. Matejczyk, Eva Hummers-Pradier

\section{E-References}

e1. Meiland R: Asymptomatic bacteriuria in women with diabetes mellitus. Arch Intern Med 2006; 166: 2222-7.

e2. Fernandez M, Raja U: UTI in men-is investigation required? www.bestbets.org/cgi-bin/bets. pl?record=00790.

e3. Knottnerus BJ, Bindels PJ, Geerlings SE, Moll van Charante EP, ter Riet G: Optimizing the diagnostic work-up of acute uncomplicated urinary tract infections. BMC Fam Pract 2008; 9: 64.

e4. Richards D, Toop L, Chambers S, Fletcher L: Response to antibiotics of women with symptoms of urinary tract infection but negative dipstick urine test results: double blind randomised controlled trial. BMJ 2005; 331: 143. Epub 2005 Jun 22.

e5. Baerheim A, Laerum E: Home-voided urine specimen in women. Diagnostic agreement with clean-catch midstream specimens. Scand J Prim Health Care 1990; 8: 207-11.

e6. Lifshitz E, Kramer L: Outpatient urine culture: does collection technique matter? Arch Intern Med 2000; 160: 2537-40.

e7. O'Neill M, Hertz-Picciotto I, Pastore LM, Weatherley BD: Have studies of urinary tract infection and preterm delivery used the most appropriate methods? Paediatr Perinat Epidemiol 2003; 17: 226-33.

e8. McDermott S, Daguise V, Mann H, Szwejbka L, Callaghan W: Perinatal risk for mortality and mental retardation associated with maternal urinary-tract infections. J Fam Pract 2001; 50: 433-7.

e9. Heckerling PS, Canaris GJ, Flach SD, Tape TG, Wigton RS, Gerber BS: Predictors of urinary tract infection based on artificial neural networks andgenetic algorithms. Int J Med Inform 2007; 76: 289-96. Epub 2006 Feb 15.

e10. Mclsaac WJ, Low DE, Biringer A, Pimlott N, Evans M, Glazier R: The impact of empirical management of acute cystitis on unnecessary antibiotic use. Arch Intern Med 2002; 162: 600-5.

e11. Grude N, Tveten Y, Jenkins A, Kristiansen BE: Uncomplicated urinary tract infections. Bacterial findings and efficacy of empirical antibacterial treatment. Scand J Prim Health Care 2005; 23: $115-9$.

e12. Verest LF, van Esch WM, van Ree JW, Stobberingh EE: Management of acute uncomplicated urinary tract infections in general practice in the south of The Netherlands. Br J Gen Pract 2000; 50: 309-10.

e13. Devillé WL, Yzermans JC, van Duijn NP, Bezemer PD, van der Windt DA, Bouter LM: The urine dipstick test useful to rule out infections. A meta-analysis of theaccuracy. BMC Urol 2004; 4: 4.

e14. Semeniuk H, Church D: Evaluation of the leukocyte esterase and nitrite urine dipstick screening tests for detection of bacteriuria in women with suspected uncomplicated urinary tract infections. J Clin Microbiol 1999; 37: 3051-2.

e15. Mignini L, Carroli G, Abalos E, Widmer M, Amigot S, Nardin JM: Accuracy of diagnostic tests to detect asymptomatic bacteriuria during pregnancy. Obstet Gynecol 2009; 113: 346-52.

e16. van der Linden MW, Westert GP, de Bakker DH, Schellevis FG: Tweede Nationale Studie naar ziekten en bevolking en in de huisartspraktijk. Klachten en aandoeningen in de bevolking en in de huisartspraktijk. Utrecht/Bilthoven: NIVEL/RIVM (2004). 